\title{
344 人工股関節ステム固定部における応力不安定性を励起する因子の推定
} Identification of the Factors on Stress Fluctuation around the Fixation Site of Femoral Stem

$\begin{array}{llll}\text { ○学 酒井 利奈(北里大院) } & \text { 学 } & \text { 雨尾 } & \text { 公暁(千葉大院) } \\ \text { 野村 寬之 (工学院大) } & \text { 正 } & \text { 馬㴊 清資 (北里大院) }\end{array}$

Rina SAKAI, Graduate School of Medical Sciences Kitasato University, 1-15-1 Kitasato Sagamihara

Kimiaki AMAO, Graduate School of Sciences and Technology, Chiba University

Hiroyuki NOMURA, Department of Engineering, Kogakuin University

Kiyoshi MABUCHI, Graduate School of Medical Sciences, Kitasato University

Key Words: FEM, 3-D Model, Fixation Site, joint prostheses, Stress Field

\section{1. 緒言}

人工股関節全置換術における人工股関節ステム固定の際，骨組 織が成長して十分な強度を得るまでの期間における固定力の確保， すなわち初期固定が問題になる. 初期固定については,広い接触面 Fit \& Fill の達成が最も重要と考えられており, 手術口ボットによって骨 髄孔を精密に掘削するといった方法が試みられている. 一方.工学分 野においては,締結要素の力学的安定状態は適切な位置への力の伝 播により得られるとされており，そのためには、接触部分を制限するこ とが望ましいことが知られている. 接触部分の限定はみかけの接触 面積减少を意味するので人工関節の固定で考えられている広い接触 面の理念と必ずしも両立しない.このことから,みかけの接触面積の 広さと力学的安定状態の間には，逆の相関があると予想できる. 良好 な初期固定の確保のために一般に考えられている理念とは, 骨組織 と人工物の界面をできるだけ広範囲に接触させること[1]，大腿骨近 位部に荷重をかけること[2]，の二つである.しかし，固体同士の接触 部分では応力が均一にならないことより[3]，広範囲で接触させた場 合，必ずしも望ましい状態が実現できるとは限らない，そこで我々は， むしろ，接触面を限定することが人工股関節の初期固定における安 定性の確保につながるのではないかと考えた：その理由は，みかけ の接触面積が広いと, 固定力を伝える接触部が確定しないためであ る. 一方, 人工関節固定部分の接触応力の理論解析において, 接触 (a)

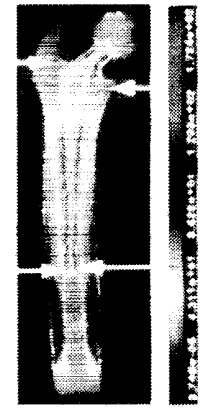

(b)

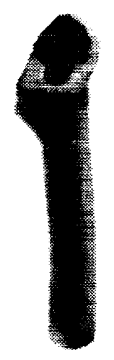

(c)

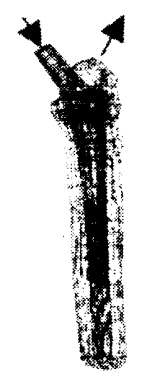

Fig. I (a) CT data of a stem and femur. (b) Virtual model of a stem and femur. (c) Mesh of the 3-D finite elements of a stem and femur. Some arrows are the load directions.

Tablel: Material Properties of Models

\begin{tabular}{lcc}
\hline & Young's Modulus $(\mathrm{G} \mathrm{Pa})$ & Poisson's Ratio \\
\hline Titanium Alloy & 111.0 & 0.29 \\
Cortical Bone & 15.5 & 0.29 \\
\hline
\end{tabular}

面が確定しないことによる解析計算の収束不能現象が発生すること が知られている. 我々は，この問題は，電子計算機アルゴリズムの 中に発生する不規則状態を誘発する因子によると考え，また，この因 子が, 人工関節の固定不良につながると考えた，そこで本研究にお いては CT 画像を用い計算機上に仮想空間を構築し理論解析による 不規則性を誘発する因子の推定を行つた.

\section{2. 対象及び方法}

解析に用いる物理定数を算出するため人工関節を設要する骨組織 のカ学的性筫の測定を行った. 実験対象として，成人男性ヒト死体大 腿骨の小切片を切り出して研磨した後にマイクロビッカース硬さ測定 装置により，骨表面から髄腔まで $100 \mathrm{~mm}$ ，大転子から遠位大腿骨ま で $2000 \mathrm{~mm}$ の大腿骨骨幹部近位皮質骨における塑性流動圧力を求 めた この值より骨組織·人工関節ステム間の真実接触面積を算出し， 生体組織が人工関節の局所的にかかる荷重に耐久できるだけの物 性値を持っているかを確認した．解析用大腿骨モデルを作成するた め, 本学、整形外科教室から入手した Fig. 1(a)に二示す人工股関節ステ 么を挿入固定した変形性股関節症患者 CT film を用い，この画像を基 に大腿骨近位部について Fig. 1(b)に示すような人工股関節ステムと骨 組織の三次元形状仮想モデルの構築をおこなった，解析対象人工 関節は，プレスフイット型人工股関節ステムの代表的なものである Fit \& Fill Type ステム(FFステム)と接触面を限定したタイプの十字ステム (IMCF ステム)2 種類とした. それぞれ，固定法に大きな犍いを有し Fit \& Fill Type ステムは骨と人工物間の全面接触固定, 十字ステムは 近位と遠位のみの接触部位限定固定である. 3 次元メッジシ仮想モデ ルは 8 つのノードを持つ 6 面体アイソパラメトリック要素から成り，Fit \& Fill Type ステムは要素数 3078, 節点数 4304, 十字ステムは要素数 3087, 節点数 4440 であつた. モデルの物性として皮筫骨、 ステムの材 料としてどちらもチタン合金を想定した. 材料特性を Table. 1 に示す. 荷重条件は、ステムのヘッドに軸方向に対し 45 度の角度で $2000 \mathrm{~N}$ の 圧縮荷重をかけ，外転筋力として軸方向に対し 60 度の角度で大転子 から $1600 \mathrm{~N}$ の荷重を引いた. 要素に分割した画像之荷重方向を Fig. 1(c)にに示す. 拘束条件は大腿骨遠位に全方向拘束とした，接触面積 と応力分布の不安定性の相関を検証するために，仮想モデルを展開 し人工股関節ステムを単純な三次元形状に置き換えた数理モデルの 構築を行った. 人工材料と骨組織界面の形状を可能なかぎりシンプ ルな数理モデルに置き換え，材料定数，質量密度の等価な接触面と して摸擬した，モデルの形状を平面と平面接触，および平面と部分接 触とし、プレプロセッサ (Hyper Mesh, Altair Engineering, USA)により 6 面体要素に分割した. Fit \& Fill Type ステムを想定した接触面積のもっ とも広いモデルはその接触面積を，人工股関節ステムの表面積と同 程度の $6400 \mathrm{~mm}^{2}$ とした. 接触部位限定モデルとして接触面積を減少

日本機械学会 (No.02-35] 第15回バイオエンジニアリング講演会 講演論文集（'03.1.21, 22 大阪） 
させたモデルを13種類構築し，面積の異なるそれぞれのモデルにつ いて, ステップ荷重に対する時間応答のパターンを同じ有限要素法解 析により求めた. 荷重条件は, 上部プレートに, 歩行時を想定した場 合の圧縮力 $2000 \mathrm{~N}[4]$ を加えた. 境界条件は，床面を3次元固定とし た，仮想モデル，数理モデルの解析にはハードウエアとして EPSON Endeavor Pro 900 を用い，解析にはソフトウェアとして動的有限要素 法解析 LS-DYNA 950(Livermore Software Technology Corporation)を 用いた. ステップ荷重に対する応答として接触応力分布とその時系列 データを求めた

\section{3. 結果および考察}

解析に用いる物理定数を算出した結果, 塑性流動圧力は 124.8 SD $23 \mathrm{M} \mathrm{Pa}$ ，真実接触面積は歩行時を想定した荷重条件のもとで 16.02 $\mathrm{mm}^{2}$ であった. この値より人工股関節十字ステム横止めピン直下に かかる最大応力は生体組織の疲労損賃度を回避できるだけの硬さと 面積を持ち, 十字ステムにかかる伈力值が妥当であることを確認した 骨と大腿骨の仮想モデルを用いた解析結果において, Fit \& Fill Type ステムと骨周囲部の応力分布は最大 $106.0 \mathrm{M} \mathrm{Pa}$ の応力が現れた. フ オンミーゼス相当応力は時間経過にともない $1.0 \mathrm{~s}$ の間に応力の部 位が不規則に移動し，近位大腿骨に応力集中が現れた(Fig.2a). 加速 度の時間変化を示す時系列データ Fig.2b から, 骨組織之人工股関節 ステム接触表面上に存在する各要菜の举動は不安定な振動状態が 続いていることが示された. 十字ステムと骨周囲部の㐫力分布は最 大 $88.0 \mathrm{MPa}$ の応力が現れた. フオンミーゼス相当応力は横止めピン で近位を支えたことで応力遮蔽を防ぎ近位大腿骨に高い応力集中は 現れなかった(Fig.3a). 加速度の時系列データ Fig.3bは，骨組織と人工 股関節ステム接触表面上の要素の挙動において振動を繰り返した後 に収束した. 数理モデルにおいて，接触形状が平面と平面であるみ かけの接触面積が最も広いモデルでは，時間経過にともない応力変 動性を示した. フオンミ一ゼス相当応力の時系列データにおいても不 安定な振動が続き収束しなかった. 接触面積が最も少ない数理モデ ルは高い応力部位の変動が少なく応力安定性を示した. 時系列デ一 夕においても，振動が徐々に減衰した，すなわち，このモデルでは， 高い応力部位の移動は少なく, 最も安定した結果が得られた. 13 種 類のモデルについて横軸に接触面積，縦軸に初期振動に対する不規 則振動の增加の程度をとり接触面積之応力分布の不安定性の相関を 検証した(Fig，4)．接触面積が増加するにともない，カオスの代表的な 挙動である不規則振動の增大が認められた. 有限要素法の構成方程 式という決定論的な要因から，接触面積が広がるにつれ応力分布に おける計算結果が不規則振動を発生するということは，広範囲接触 応力場において決定論的力オスが存在するといえる[6]. このことから. 不安定なカオス状態を回避するために接触面積を制限するという方 法が考えられる. 理論解析においてカオスを指標とした予測法や制 御理論を発展させることにより, 人工股関節の固定法に新しい概念を 導入できる可能性が示晙された.

\section{参考文献}

[1] Iguchi $\mathrm{H}$, J. Hua et al.: Accuracy of using radiographs for custom hip stem design. J Arthrop 11(3): 312-321, 1996.

[2] Jack M. Bert : Custom total hip arthroplasty. J Arthrop 11(8): 905-915, 1996.

[3] JI. A ガーリン: 佐藤 常三 (訳。弾性接触論 東京, 現代工学社 7, 1997

[4] 笹田 直、馬㴊 清盗他: バイオトライボロジーー関答の摩擦之澗滑—. 東 京, 産業Fig 書株式会社 25, 1988.

[5] 川原柇治: ソリトンからカオスヘー非線形方程式の世界へー. 東京. 株式 会社朝倉畫店, 25, 1993

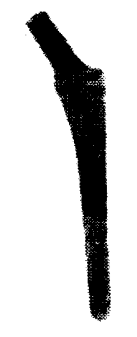

0.0

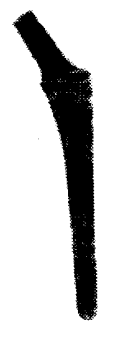

0.3

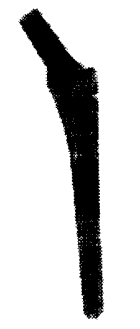

0.7

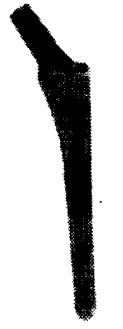

1.0 Time $[\mathrm{s}]$
Fig. 2a Calculated fluctuation of von Mises equivalent stress of the surface of the FF stem.

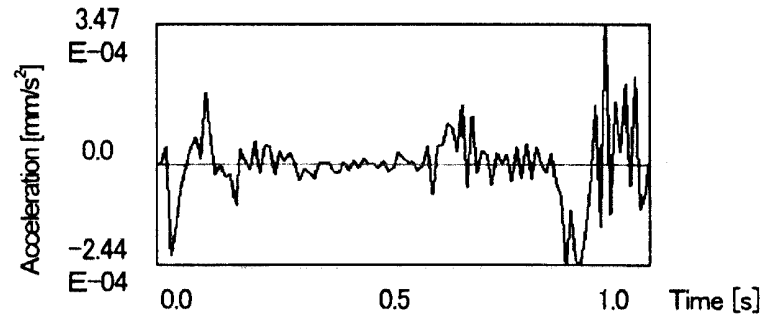

Fig. $2 \mathrm{~b}$ Calculated step response of the acceleration of the contact surface of the FF stem.

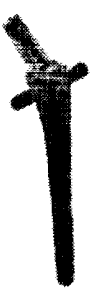

0.0

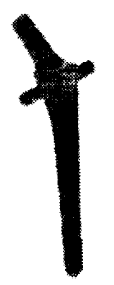

0.3

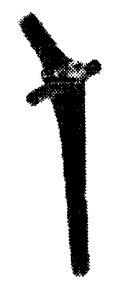

0.7

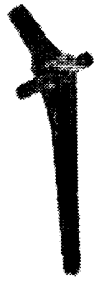

1.0 Time $[\mathrm{s}]$
Fig. 3a Calculated fluctuation of von Mises equivalent stress of the surface of the IMCF stem.

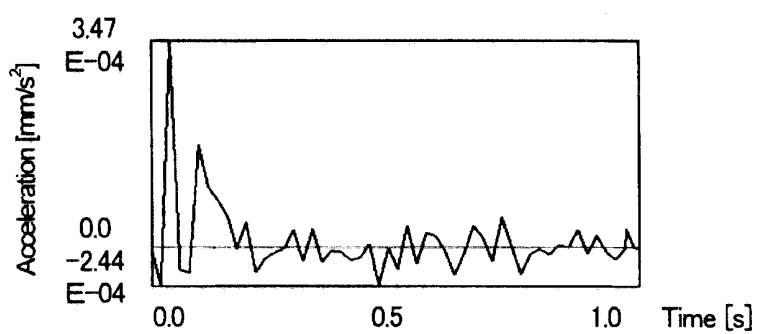

Fig. $3 \mathrm{~b}$ Calculated step response of the acceleration of the contact surface of the IMCF stem.

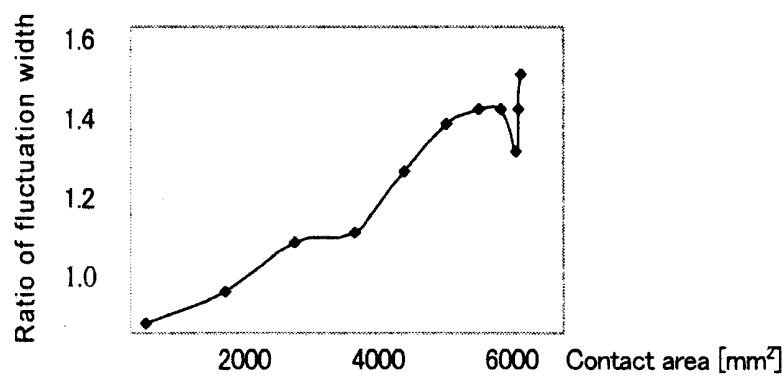

Fig. 4 Relationship between fluctuation of stress distribution and the contact area of the mathematical model. 